DOI: 10.33766/2524-0323.92.224-233

УДК 342.951:351.773:614.46

В. І. Мотиль,

кандидат юридичних наук,

старший науковий співробітник, старший науковий співробітник наукової лабораторії

3 проблем протидії злочинності ННI № 1

Національної академії внутрішніх справ

(м. Київ, Україна)

e-mail: viktormotyl2020@gmail.com

iDhttps://orcid.org/0000-0003-1790-6741

Я. О. Дякін,

кандидат юридичних наук,

провідний науковий співробітник наукової лабораторії $з$ проблем протидії злочинності ННІ № 1

Національної академії внутрішніх справ

(м. Київ, Україна)

e-mail: v_nemish@ukr.net

iDhttps://orcid.org/0000-0002-6943-0151

\title{
ПРОБЛЕМИ АДМІНІСТРАТИВНОЇ ВІДПОВІДАЛЬНОСТІ ЗА ПОРУШЕННЯ ПРАВИЛ ЩОДО КАРАНТИНУ ЛЮДЕЙ
}

У статті досліджуються актуальні проблеми адміністративної відповідальності за порушення правил карантину людей, пов' язані насамперед з бланкетною диспозицією ст. 44-3 КУпАП, спільними рисами форм об'єктивної сторони адміністративного правопорушення, передбаченого ст. 44-3 КУпАП, та злочину, передбаченого ст. 325 КК України, а також обмеженням гарантованих Конституцією прав та свобод людини й громадянина через запровадження на території України окремих правил карантину у зв'язку зі стрімким поширенням гострої респіраторної хвороби COVID-19, спричиненої коронавірусом SARS-CoV-2. Розроблено пропозищії щодо вирішення зазначених проблем, зокрема шляхом диференціації адміністративної відповідальності за вказані діяння, створення чіткого переліку нормативно-правових актів порушення яких може мати наслідком притягнення до адміністративної відповідальності за певні діяння, а також запровадження відповідних заборон у суворій згідності з Конституцією України, зокрема після введення надзвичайного стану або внесення відповідних змін до Основного закону української держави.

Ключові слова: адміністративна відповідальність, карантин, коронавірус, адміністративне правопорушення, інфекційні хвороби, правила карантину людей.

Постановка проблеми. Здоров'я населення є об'єктом правової охорони в будь-якій цивілізованій країні. Суспільсто протягом усього періоду свого існування пережило не одну епідемію. Не є винятком і пандемія, що виникла в результаті стрімкого поширення територією України гострої респіраторної хвороби COVID-19, спричиненої коронавірусом SARS-CoV-2. Однак для цього слід вживати низку медичних, організаційних, економічних, соціальних та правових заходів, серед яких важливе місце відводиться підставам адміністративної відповідальності за порушення

(С) Мотиль B. I., 224

Дякін Я. О., 2020 
правил щодо карантину людей, які передбачені в ст. 44-3 КУпАП. Відповідальність за цією статтею пов' язана з непопулярними серед населення заходами, що полягають, певною мірою, в обмеженні окремих прав і свобод громадян України. Негативна реакція суспільства на вказані заходи також обумовлена посиленням відповідальності за порушення санітарних правил і норм щодо запобігання інфекційним хворобам та масовим отруєнням. Законом України «Про внесення змін до деяких законодавчих актів України, спрямованих на запобігання виникненню і поширенню коронавірусної хвороби (COVID-19)» від 17 березня 2020 р. доповнено КУпАП ст. 44-3 КУпАП, яка передбачає накладення штрафу на громадян від однієї до двох тисяч неоподатковуваних мінімумів доходів громадян і на посадових осіб - від двох до десяти тисяч неоподатковуваних мінімумів доходів громадян.

Слід погодитися з тим, що така поспішність прийнятих Верховною Радою України змін до законодавства була викликана необхідністю вжиття активних заходів з боку інститутів держави, спрямованих на захист населення країни від надзвичайно небезпечної хвороби, викликаної вірусною інфекцією, необхідністю збереження життя і здоров'я людини, населення в цілому [1, с. 158].

Зазначені правові інструменти (ст. 325 КК України та ст. 44-3 КУпАП) стали потужним фактором впливу на процес протидії поширенню на території України гострої респіраторної хвороби COVID-19, спричиненої коронавірусом SARS$\mathrm{CoV}$ - 2. Однак уже перші факти застосування зазначених норм на практищі, насамперед ст. 44-3 КУпАП, продемонстрували суттєві прорахунки законодавця в конструюванні підстав відповідальності за протиправні діяння, пов'язані з порушенням правил щодо карантину людей. А тому існує необхідність у проведенні комплексного дослідження найбільш значних проблем, що виникають на практищі під час притягнення до адміністративної відповідальності за ст. 44-3 КУпАП.

Аналіз останніх досліджень і публікацій. Питання адміністративної відповідальності за порушення правил карантину щодо людей розглядали у своїх дослідженнях А. А. Вознюк, В. В. Крикун, С. С. Ковальова, С. В. Курінний, М. А. Самбор, С. С. Чернявський та ін. Однак чимало проблем адміністративної відповідальності за протиправні діяння, передбачені ст. 44-3 КУпАП, залишаються поза межами комплексного дослідження.

Формулювання цілей. Ураховуючи викладене, метою даної статті є дослідження актуальних проблем адміністративної відповідальності за порушення правил карантину людей та розроблення шляхів їх розв' язання.

Виклад основного матеріалу. Під час конструювання адміністративно-правової норми, передбаченої ст. 44-3 КУпАП, законодавцем використано бланкетну диспозицію. Такий підхід законодавця цілком аргументовано піддано критищі вченими. На думку В. В. Крикуна, це негативно впливає на розмежування компетенщії тих органів, які за законом мають право складати протоколи про адміністративні правопорушення за цією статтею КУпАП [2, с. 158]. С. В. Курінний з цього приводу зауважує, що бланкетний характер змісту диспозищії ст. 44-3 КУпАП значно ускладнює самостійне ознайомлення більшості громадян із чинними заборонами, які містяться в кількох нормативно-правових актах, зокрема й підзаконного рівня [3, с. 149]. Має рацію і С. С. Ковальова, зазначаючи, що стосовно до санітарно-гігіє- 
нічних, санітарно-протиепідемічних правил і норм, про порушення яких зазначається у ст. 44-3 КУпАП, то в тексті Закону «Про захист населення від інфекційних хвороб» вони відсутні. Ці правила і норми - нормативно-правові акти (накази, інструкції, правила, положення тощо) центрального органу виконавчої влади, що забезпечує формування державної політики у сфері охорони здоров'я, вимоги яких спрямовані на запобігання виникненню та поширенню інфекційних хвороб. Зважаючи на множинність та розпорошеність цих норм у чисельних нормативно-правових актах одночасно з необхідністю спеціальних знань при тлумаченні їх змісту, призвело до значних труднощів при реалізації правової конструкціїст. 44-3 КУпАП на практиці [4, с. 162].

У судовій практиці через це мають місце випадки допущення помилок під час складання протоколів про адміністративне правопорушення за вказаною статтею. Наприклад, суддя Стрийського міськрайонного суду Львівської області, розглянувши матеріали про притягнення до адміністративної відповідальності ОСОБА_1 за те, що вона, будучи продавцем даного магазину, приймала відвідувачів без засобів індивідуального захисту, а саме: медичної маски та рукавичок, чим порушила вимоги постанов КМУ № 211 від 12.03.2020 та № 641 від 22.07.2020, вчинивши правопорушення, передбачене ст. 44-3 КУпАП. Дослідивши протокол про адміністративне правопорушення та додані до нього матеріали, суд дійшов висновку, що вони підлягають поверненню для належного оформлення, посилаючись на те, що формулювання суті правопорушення не може обмежуватись цитуванням нормативного акта, а повинно містити відомості про вчинене правопорушення, відповідно до диспозищії ст. 44-3 КУпАП, з конкретизацією суті правопорушення. Тобто, у протоколі має бути посилання на відповідний підпункт та пункт постанови Кабінету Міністрів України [5]. Така практика повернення протоколів про адміністративні правопорушення за вчинення правопорушення, передбаченого ст. 44-3 КУпАП, разом із долученими до них матеріалами для належного оформлення є досить поширеною. Хоча видається, що немає особливих проблем щодо того, щоб поліцейські зробили посилання на відповідний підпункт та пункт постанови Кабінету Міністрів України. Однак, чому досить часто допускають такі правопорушення - незрозуміло.

3 правилами, викладеними в Постановах Кабінету Міністрів України, які приймалися за період пандемії («Про запобігання поширенню на території України коронавірусу COVID-19» від 11 березня 2020 р. № 211, «Про встановлення карантину з метою запобігання поширенню на території України гострої респіраторної хвороби COVID-19, спричиненої коронавірусом SARS-CoV-2, та етапів послаблення протиепідемічних заходів» від 20 травня 2020 р. № 392, «Про встановлення карантину та запровадження посилених протиепідемічних заходів на території із значним поширенням гострої респіраторної хвороби COVID-19, спричиненої коронавірусом SARS-CoV-2» від 22 липня 2020 р. № 641), біль-менш усе зрозуміло: $\epsilon$ чіткі заборони, яких слід дотримуватися. Завдяки потужній інформаційній роботі органів державної влади положення цих нормативно-правових актів систематично доводяться до відома населення. Більш складною є ситуація з іншими правилами та нормами, порушення яких може мати наслідком притягнення до відповідальності за ст. 44-3 КУпАП. 
Навіть спеціалістам у галузі права, на перший погляд, не просто розібратися i чітко визначити порушення яких норм може мати наслідком притягнення до адміністративної відповідальності за ст. 44-3 КУпАП. Проблема ще й ускладнюється тим, що порушення правил карантину може мати наслідком як притягнення до адміністративної, так і кримінальної відповідальності, адже у ст. 44-3 КУпАП встановлено відповідальність за порушення правил щодо карантину людей, санітарногігієнічних, санітарно-протиепідемічних правил і норм, передбачених Законом України «Про захист населення від інфекційних хвороб», іншими актами законодавства, а також рішень органів місцевого самоврядування з питань боротьби з інфекщійними хворобами. Водночас ст. 325 КК України передбачає підстави кримінальної відповідальності за порушення правил та норм, встановлених з метою запобігання епідемічним та іншим інфекційним хворобам, а також масовим неінфекщійним захворюванням (отруєнням) і боротьби з ними, якщо такі дії спричинили або завідомо могли спричинити поширення цих захворювань. Незважаючи на те, що текстуально диспозиції ст. 44-3 КУпАП та ст. 325 КК України різняться, порушення правил карантину є формою об'єктивної сторони обох складів правопорушень. Різниця між ними в тому, що відповідне адміністративне правопорушення сконструйоване як таке, що має формальний склад, натомість склад кримінального правопорушення належить до матеріальних. До наслідків вказаного злочину належать спричинення або загроза спричинення епідемічних та інших інфекційних хвороб, масових неінфекщійних захворювань (отруєнь) (ч. 1 ст. 325 КК України), а також загибель людей чи інші тяжкі наслідки (ч. 1 ст. 325 КК України). Більшість кримінально-правових наслідків дає можливість відносно легко відмежувати цей злочин від адміністративного правопорушення, передбаченого ст. 44-3 КУпАП. Однак такий наслідок, як загроза спричинення відповідних захворювань, викликає труднощі. Оскільки значна частина правил карантину в результаті їх порушення несе в собі потенційну загрозу зараження відповідною хворобою.

Як слушно зауважують А. А. Вознюк та С. С. Чернявський, наявність такого наслідку, як «створення загрози поширення інфекційних хвороб, масових неінфекційних захворювань (отруєнь)», охоплює широкий спектр потенційно можливих злочинних діянь, адже, унаслідок порушення більшості встановлених заборон, постає можливість зараження інших осіб, а отже, і поширення інфекційної хвороби. Така загроза може виникнути, наприклад, у результаті перебування в громадських місцях без вдягнутих засобів індивідуального захисту, зокрема респіратора або захисної маски. Якщо така особа вже $є$ хворою, то внаслідок перебування без маски ступінь вірогідності зараження сторонніх осіб значно вищий, ніж у тому випадку, коли вона була б у захисній масці [6, с. 11-12]. Варто також додати, що 3 огляду на особливості гострої респіраторної хвороби COVID-19, спричиненої коронавірусом SARS-CoV-2, вона може протікати безсимптомно, тому хворий і не підозрюватиме, що є носієм відповідного захворювання. Водночас, якщо він не застосовує відповідні засоби захисту, то наражає в певних випадках на небезпеку зараження сторонніх осіб. Однак на практиці такі дії кваліфікують як адміністративне правопорушення. Наприклад, згідно з протоколом про адміністративне правопорушення, 25.10.2020 року, о 23:12 год., ОСОБА_1, без вдягнутих засобів індиві- 
дуального захисту, зокрема, респіратора чи захисної маски, перебувала в громадському транспорті (тролейбус № 15-А), який рухався в м. Луцьк по пр-ту Соборності. Дії ОСОБА_1 кваліфіковані за ст. 44-3 КУпАП [7].

Водночас окремі порушення правил карантину апріорі не можуть мати відповідних суспільно небезпечних наслідків. Наприклад, 23.11.2020 року, приблизно о 08 год. 28 хв., громадянка ОСОБА_1 перебувала на вулищі, не маючи при собі документа, що посвідчує особу або громадянство, чим порушила п.п.2 п.10 постанови КМУ № 641 від 22.07.2020p. та вчинила правопорушення, передбачене ч. 1 ст. 44-3 КУпАП [8].

Ще однією проблемою, на яку варто звернути увагу, є питання законності та відповідності положенням Конституції України окремих заборон, що стосуються правил карантину. М. А. Самбор слушно зауважує, що неприпустимо ставити під загрозу позбавлення чи обмеження прав і свобод людини та громадянина в угоду протидії хворобі. 3 іншого боку, запровадження заходів, які прямо призводять до обмеження прав і свобод людини та громадянина мають відповідати соціально значущій цілі та підтверджувати те, що людина, їі права і свободи є найвищою соціальною цінністю, повинні бути максимально досконалими, а не ухваленими в угоду політичній доцільності. Причому жодних переваг чи привілеїв не має бути залежно від статі, національності, місця проживання, соціального статусу чи матеріального забезпечення людини [1, с. 158].

Деякі передбачені постановою Кабінету Міністрів України «Про запобігання поширенню на території України коронавірусу COVID-19» заборонені діяння оскаржують у судах через невідповідність окремих заборон Конституції України. Вони обмежують права та свободи людини й громадянина, які гарантовані Конституцією України. На це слушно звернули увагу вчені $[9$, с. 23; 10, с. 163; 11, с. 131; 12, c. 147].

Дійсно, відповідно до ст. 64 Конституції України, конституційні права і свободи людини й громадянина не може бути обмежено, крім випадків, передбачених Конституцією України. До таких випадків у цій статті віднесено наявність умов воєнного або надзвичайного стану: «В умовах воєнного або надзвичайного стану можуть встановлюватися окремі обмеження прав і свобод із зазначенням строку дії цих обмежень [6, с. 11-12; 13]. 3 огляду на це окремі заборони, передбачені вищезазначеними Постановами Кабінету Міністрів України, можуть встановлюватися після запровадження надзвичайного стану.

Висновки. Застосування заходів примусу у формі притягнення до адміністративної відповідальності за порушення правил щодо карантину людей має відбуватися виключно у законний спосіб. Водночас цьому суттєво перешкоджають недоліки конструкції ст. 44-3 КУпАП, яка має бланкетний характер і відсилає до невизначеного переліку нормативно-правових актів, які містять відповідні правила щодо карантину людей, санітарно-гігієнічні, санітарно-протиепідемічні правила і норми. Вихід із проблеми вбачається, зокрема, у диференщіації адміністративної відповідальності за вказані діяння шляхом розподілу ст. 44-3 КУпАП на окремі частини, а також шляхом створення чіткого переліку нормативно-правових актів, порушення яких може мати наслідком притягнення до адміністративної 
відповідальності за ці діяння. Окрім того, встановлення відповідних заборон, насамперед пов'язаних із карантином, слід здійснювати в суворій відповідності 3 Конституцією України, зокрема після введення надзвичайного стану або внесення відповідних змін до Основного закону української держави, які дозволяли б здійснювати такі обмеження у виняткових обставинах, якими, очевидно, слід вважати й сучасну пандемію.

\section{Використані джерела:}

1. Самбор М. А. Склад адміністративного правопорушення шодо порушення правил карантину людей. Вісник Луганського державного університету внутрішніх справ імені Е. О. Дідоренка. 2020. № 2(90). С. 155-170. DOI : https:/ / doi.org/10.33766/2524-0323.90.155-170.

2. Крикун В. В. Об'єктивні особливості адміністративних правопорушень, передбачених статтею 44-3 Кодексу України про адміністративні правопорушення та їх вплив на сферу повноважень Національної поліції України. Вісник Харківського національного універсиmету внутрішніх справ. 2020. № 89 (2). C. 153-163. DOI : https:/ / doi.org/10.32631/v.2020.2.15.

3. Курінний Є. В. Про аксіологічну сутність адміністративних штрафів. Вісник Запорізького національного університету. Вип. № 1. 2020. С.144-150. DOI : https://doi.org/10. 26661/2616-9444-2020-1-22.

4. Ковальова С. С. Відповідальність за порушення карантину та санітарних правил і норм щодо запобігання поширенню коронавірусної інфекції (COVID-19) в Україні. Науково-практичний журнал «Право. Людина. Довкілля». 2020. № 11(2). С. 158-168. DOI : https:// doi.org/10.31548/law2020.02.019.

5. Постанова судді Стрийського міськрайонного суду Львівської області від 04 грудня 2020 року. Справа № 456/4527/20. URL: https:/ / reyestr.court.gov.ua/Review/93319676. (дата звернення: 28.11.2020)

6. Вознюк А., Чернявський С. Порушення правил і норм щодо запобігання COVID19: актуальні проблеми кримінальної та адміністративної відповідальності. Юридичний часопис Національної академії Внутрішніх справ. 2020. № 19 (1). C. 8-19. DOI : https://doi.org/ 10.33270/04201901.8.

7. Постанова судді Луцького міськрайонного суду Волинської області від 04 грудня 2020 року. Справа № 161/18443/20. URL : https://reyestr.court.gov.ua/Review/93302844. (дата звернення: 28.11.2020)

8. Постанова судді Інгулецького районного суду міста Кривого Рогу Дніпропетровської області від 04 грудня 2020 року. Справа № 213/4149/20. URL : https:/ / reyestr. court. gov.ua/ Review/93303786. (дата звернення: 28.11.2020)

9. Чернявський С. С., Вознюк А. А. Проблеми відповідальності за порушення правил і норм щодо запобігання поширенню COVID-19. Кримінологічна теорія і практика: досвід, проблеми сьогодення та шляхи їх вирішення [Текст] : матеріали міжвузів. наук.практ. круглого столу (Київ, 28 трав. 2020 р.) / у 2-х ч. [редкол.: В. В. Чернєй, С. Д. Гусарєв, С. С. Чернявський та ін.]. Київ : Нац. акад. внутр. справ, 2020. Ч. 1. С. 20-26.

10. Пилипів Р., Тимчишин А. Адміністративна відповідальність за порушення правил щодо карантину людей: проблеми та перспективи. Юридичний вісник. 2020. № (3). С. 163-169. DOI : https://doi.org/10.32837/yuv.v0i3.1937.

11. Світличний О. Діяльність публічної адміністрації у сфері протидії коронавірусу Covid-19. Науково-практичний журнал «Право. Людина. Довкіля». 2020. № 11(2). С. 124-132. DOI : https://doi.org/10.31548/law2020.02.015. 
12. Бугайчук К. Л. Питання вдосконалення положень чинного законодавства України щодо запобігання виникненню і поширенню коронавірусної хвороби COVID-19. Право $і$ безпека. 2020. № 2 (77). C. 147-155. DOI : https://doi.org/10.32631/pb.2020.2.20. (дата звернення: 28.11.2020)

13. Конституція України від 28 черв. 1996 р. URL : https:/ zakon.rada. gov.ua/laws/ show $/ 254 \%$ D0\%BA/96-\%D0\%B2\%D1\%80\#Text. (дата звернення: 28.11.2020)

\section{References:}

1. Sambor, M. A. (2020). Sklad administratyvnoho pravoporushennia shodo porushennia pravyl karantynu liudei. Visnyk Luhanskoho derzhavnoho universytetu vnutrishnikh sprav imeni E. O. Didorenka - Bulletin of Luhansk State University of Internal Affairs named after E. Didorenko, 2(90), 155-170. DOI : 10.33766/2524-0323.90.155-170. [in Ukrainian].

2. Krykun, V. V. (2020). Obiektyvni osoblyvosti administratyvnykh pravoporushen, peredbachenykh statteiu 44-3 Kodeksu Ukrainy pro administratyvni pravoporushennia ta yikh vplyv na sferu povnovazhen Natsionalnoi politsii Ukrainy. Visnyk Kharkivskoho natsionalnoho universytetu vnutrishnikh sprav - Bulletin of Kharkiv National University of Internal Affairs, 89 (2), 153-163. DOI : https://doi.org/10.32631/v.2020.2.15. [in Ukrainian].

3. Kurinnyi, Ye. V. (2020). Pro aksiolohichnu sutnist administratyvnykh shtrafiv. Visnyk Zaporizkoho natsionalnoho universytetu - Bulletin of Zaporizhia National University, 1, 144-150. DOI : https://doi.org/10.26661/2616-9444-2020-1-22. [in Ukrainian].

4. Kovalova, S. S. (2020). Vidpovidalnist za porushennia karantynu ta sanitarnykh pravyl i norm shchodo zapobihannia poshyrenniu koronavirusnoi infektsii (COVID-19) v Ukraini. Naukovo-praktychnyi zhurnal «Pravo. Liudyna. Dovkillia»-Scientific and practical journal «Law. Human. Environment», 11(2), 158-168. DOI : https://doi.org/10.31548/law2020.02.019. [in Ukrainian].

5. Postanova suddi Stryiskoho miskraionnoho sudu Lvivskoi oblasti vid 04 hrudnia 2020 roku. Sprava № 456/4527/20. Sait "Yedynyi derzhavnyi reiestr sudooykh rishen" - Site "Unified state register of court decisions". URL : https://reyestr.court.gov.ua/Review/93319676. [in Ukrainian].

6. Vozniuk, A., Cherniavskyi, S. (2020). Porushennia pravyl i norm shchodo zapobihannia COVID-19: aktualni problemy kryminalnoi ta administratyvnoi vidpovidalnosti. Yurydychnyi chasopys Natsionalnoi akademii vnutrishnikh sprav - Law Magazine of the National Academy of Internal Affairs, 19 (1), 8-19. DOI : https://doi.org/10.33270/04201901.8. [in Ukrainian].

7. Postanova suddi Lutskoho miskraionnoho sudu Volynskoi oblasti vid 04 hrudnia 2020 roku. Sprava № 161/18443/20. Sait "Yedynyi derzhavnyi reiestr sudooykh rishen" - Site "Unified state register of court decisions". URL : https://reyestr.court.gov.ua/Review/93302844. [in Ukrainian].

8. Postanova suddi Inhuletskoho raionnoho sudu mista Kryvoho Rohu Dnipropetrovskoi oblasti vid 04 hrudnia 2020 roku. Sprava № 161/18443/20. Sait "Yedynyi derzhavnyi reiestr sudooykh rishen" - Site "Unified state register of court decisions". URL : https:/ / reyestr. court. gov. ua/Review/93302844. (дата звернення: 30.11.2020). [in Ukrainian].

9. Cherniavskyi, S., Vozniuk, A. (2020). Problemy vidpovidalnosti za porushennia pravyl i norm shchodo zapobihannia poshyrenniu COVID-19. Kryminolohichna teoriia i praktyka: dosvid, problemy sohodennia ta shliakhy yikh vyrishennia [Tekst]: materialy mizhouziv. nauk.-prakt. kruhloho stolu (Kyiv, 28 trav. 2020 r.). Kyiv : Nats. akad. vnutr. sprav, 1, 20-26. [in Ukrainian].

10. Pylypiv, R., Tymchyshyn, A. (2020). Administratyvna vidpovidalnist za porushennia pravyl shchodo karantynu liudei: problemy ta perspektyvy [Administrative liability for violation of human quarantine rules: problems and prospects]. Yurydychnyi visnyk, Legal Bulletin, (3), 163169. DOI : https://doi.org/10.32837/yuv.v0i3.1937. [in Ukrainian]. 
11. Svitlychnyi, O. (2020). Diialnist publichnoi administratsii u sferi protydii koronavirusu Covid-19. Naukovo-praktychnyi zhurnal «Pravo. Liudyna. Dovkillia»-Scientific and practical journal "Law. Human. Environment", 11(2), 124-132. DOI : https://doi.org/10.31548/law2020.02.015. [in Ukrainian].

12. Buhaichuk, K. L. (2020). Pytannia vdoskonalennia polozhen chynnoho zakonodavstva Ukrainy shchodo zapobihannia vynyknenniu i poshyrenniu koronavirusnoi khvoroby COVID19. Pravo i bezpeka-Law and security, 2 (77), 147-155. DOI : https://doi.org/10.32631/pb.2020.2.20. [in Ukrainian].

13. Konstytutsiia Ukrainy vid 28 cherv. 1996 r. URL : https://zakon.rada.gov .ua/laws/ show $/ 254 \%$ D0\%BA/96-\%D0\%B2\%D1\%80\#Text. [in Ukrainian].

Стаття надіӥшла до редколегіï 30.11.2020

Мотыль В. И., кандидат юридических наук, старший научный сотрудник, старший научный сотрудник научной лаборатории по проблемам противодействия преступности УНИ № 1

Национальной академии внутренних дел (г. Киев, Украина)

Дякин Я. А., кандидат юридических наук, ведущий научный сотрудник научной лаборатории по проблемам противодействия преступности УНИ № 1

Национальной академии внутренних дел (г. Киев, Украина)

\section{ПРОБЛЕМЫ АДМИНИСТРАТИВНОЙ ОТВЕТСТВЕННОСТИ ЗА НАРУШЕНИЯ ПРАВИЛ КАРАНТИНА ЛЮДЕЙ}

В статье исследуются актуальные проблемы административной ответственности за нарушения правил карантина людей, связанные прежде всего с бланкетной диспозицией ст. 44-3 КобАП, общими чертами форм объективной стороны административного правонарушения, предусмотренного ст. 44-3 КобАП, и преступления, предусмотренного ст. 325 УК Украины, а также ограничением гарантированных Конституцией прав и свобод человека и гражданина, в связи с введением на территории Украины отдельных правил карантина из-за стремительного распространения острой респираторной болезни COVID-19, вызванной коронавирусом SARS-CoV-2. Разработаны предложения по решению указанных проблем, в частности путем дифференциации административной ответственности за указанные деяния, создания четкого перечня нормативно-правовых актов, нарушение которых может привести к привлечению к административной ответственности за соответствующие действия, а также введения соответствующих запретов в строгом соответствии с Конституцией Украины, в частности, после введения чрезвычайного положения или внесения соответствующих изменений в Основной закон украинского государства. 
Ключевые слова: административная ответственность, карантин, коронавирус, административное правонарушение, инфекционные болезни, правила карантина людей.

Motyl V,

$\mathrm{Ph}$. D. in Law, Senior Research Fellow, Senior researcher of the Laboratory of problems of combating crime of the Educational and Scientific Institute № 1 of the National Academy of Internal Affairs (Kyiv, Ukraine)

Diakin Ya.,

$\mathrm{Ph} . \mathrm{D}$. in Law, Leading researcher of the Laboratory of problems of combating crime of the Educational and

Scientific Institute № 1 of the National Academy of Internal Affairs

(Kyiv, Ukraine)

\section{PROBLEMS OF ADMINISTRATIVE RESPONSIBILITY FOR VIOLATION OF RULES REGARDING PEOPLE'S QUARANTINE}

The article examines current problems of administrative liability for violations of rules of quarantine of people, primarily related to the blanket disposition of Art. 44-3 of the Code of Administrative Offenses, common features of the forms of the objective side of the administrative offense under Art. 44-3 of the Code of Administrative Offenses, and the crime under Art. 325 of the Criminal Code of Ukraine, as well as restrictions on constitutionally guaranteed human and civil rights and freedoms, which in connection with the introduction of certain quarantine rules in Ukraine due to the rapid spread of acute respiratory disease COVID-19 caused by coronavirus SARS-CoV-2.

It is established that in judicial practice in this regard there are cases of errors in the preparation of protocols on administrative offenses under Art. 44-3 of the Code of Administrative Offenses. It is argued that even specialists in the field of law at first do not just understand and clearly identify violations of which rules may result in administrative prosecution under Art. 44-3 of the Code of Administrative Offenses. The problem is further complicated by the fact that violation of quarantine rules can result in both administrative and criminal prosecution. Despite the fact that the textual disposition of Art. 44-3 of the Code of Administrative Offenses and Art. 325 of the Criminal Code of Ukraine differ, violation of quarantine rules is a form of the objective side of both offenses. The difference between them is that the relevant administrative offense is constructed as having a formal composition, while composition of a criminal offense is a material one. The consequences of this crime include causing or threatening to cause epidemic and other infectious diseases, mass non-communicable diseases (poisonings) (Part 1 of Art. 325 of the Criminal Code of Ukraine), as well as death or other serious consequences (Part 1 of Article 325 of the Criminal Code of Ukraine). Most of criminal consequences make it relatively easy to distinguish this crime from the administrative offense under Art. 44-3 of the Code of Administrative Offenses. However, such a consequence as the threat of causing the respective diseases causes difficulties. Because a significant part of the quarantine rules as a result of their violation carries a potential risk of infection with the disease. 
Proposals have been developed to address these issues, in particular by differentiating administrative liability for these acts, creating a clear list of regulations, violation of which may result in administrative liability for such acts, as well as the introduction of relevant prohibitions in strict accordance with the Constitution of Ukraine, in particular after introduction of a state of emergency or making appropriate amendments to the Basic Law of the Ukrainian state.

Keywords: administrative liability, quarantine, coronavirus, administrative offense, infectious diseases, rules of quarantine of people.

DOI: $10.33766 / 2524-0323.92 .233-244$

УДК 342.95:332.87

Ю. В. Тарасюк, заслужений юрист України, перший заступник директора КП «Житлоінвестбуд - УКБ»

(м. Київ, Україна)

e-mail: tarasyuk_y@ukr.net

iDhttps:/ / orcid.org/0000-0001-8352-7120

\section{ГЕНЕЗА АДМІНІСТРАТИВНО-ПРАВОВОГО ЗАБЕЗПЕЧЕННЯ ЖИТЛОВОГО БУДІВНИЦТВА В УКРАЇНІ (3 ЧАСІВ ІСНУВАННЯ СРСР І ДО СЬОГОДНІ)}

Стаття присвячена здійсненню історико-правового аналізу становлення та розвитку адміністративно-правового забезпечення житлового будівнищтва в Україні 3 часів існування СРСР в і до сьогодні. Обгрунтовано, що за роки панування в Україні радянського режиму було сформовано досить розгалужену систему нормативно-правових актів із питань будівнищтва, що складалася із загальносоюзних та республіканських актів, деякі з яких $є$ і досі чинними. Під час аналізу сучасного етапу розвитку адміністративно-правового забезпечення будівельної сфері було з'ясовано, що основним питанням, яке слід вирішити законодавцю, є забезпечення здійснення систематизації законодавства у вказаній сфері, з метою його приведення у єдину, злагоджену систему з чітко виз наченим стрижневим галузевим Законом.

Ключові слова: історико-правовий аналіз, становлення, розвиток, адміністративно-правове забезпечення, житлове будівництво, СРСР, незалежність, Україна.

Постановка проблеми. Однією з надзвичайно важливих умов нормального існування людини є житло, наявність та стан якого в значній мірі обумовлює рівень їі благополуччя, задоволеності життям. Тож існуючі в Україні проблеми у сфері житлового будівництва, а також прогалини в науково-теоретичному підгрунті цієї проблематики обумовлюють актуальність та доцільність проведення комплексного дослідження адміністративно-правового забезпечення житлового будівництва. Вбачається за доцільне вивчити генезу зазначених засад, оскільки з'ясування та аналіз історико-правових аспектів їх виникнення, становлення і розвитку дозволяє уникнути повторення помилок минулого та сприяє визначенню перспектив подальшого удосконалення й розвитку адміністративно-правового забезпечення житлового будівництва в Україні.

(C) Тарасюк Ю. В., 2020 